\title{
TRANSBORDER COMMEMORATION ROUTES AND RITUALS
}

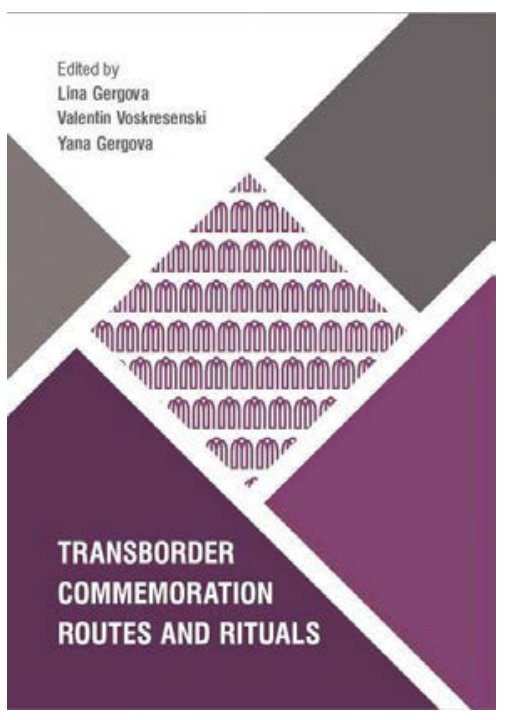

\section{Gergova, V. Voskresenski, Y. Gergova (eds.). Sofia: Paradigma, 2019, 262 pp.}

The volume 'Transborder Commemoration Routes and Rituals' edited by Lina Gergova, Valentin Voskresenski, and Yana Gergova (Sofia: Paradigma, 2019) is a result of the work of a team based at the Institute of Ethnology and Folklore Studies at the Bulgarian Academy of Sciences on the project 'Constructing National Cultural Heritage Abroad. Transborder Pilgrimage and Commemorative Practices' funded by the Bulgarian National Science Fund. The issues that the book discusses are among the most important for present-day ethnology, cultural anthropology and folklore studies - constructing national identity abroad in the context of transborder commemorative and pilgrimage traditions, rituals, and practices. Both the subject and the area of the study are quite wide - from Europe to the Middle and Far East. The book is interdisciplinary - methods and approaches from the fields of ethnic and folklore studies as well as of sociology and social anthropology have been used. The volume consists of 262 pages and is rich in maps, diagrams and pictures.

The edition starts with an editorial (by L. Gergova), which outlines the horizon of studies on borders and identity, national and transnational, history and current trends of presenting the national beyond its borders, as well as the variety of commemorative practices - pilgrimages, rituals, monuments, and the whole palette of national symbols and mechanisms and forms of national heritage representations abroad. The book contains 15 articles that are based 
on presentations at the international conference 'Transborder Commemoration Routes and Rituals' held in Sofia, Bulgaria, on 1-2 November 2018.

Traditionally, pilgrimage practices are connected with religious and evolved terms labeling them in the postmodern secular societies, and their transformations in the context of national and transnational from the perspective of diverse religious denominations. There are studies on Catholicism (V. Voskresenski. Collective Transborder Commemorations and Pilgrimage: The Case of Bulgarian Catholics) and Orthodoxy in the context of transnational character of global denominations, on the one hand, and reconsidering and valorizing the national, on the other (T. Matanova. Journeys to Mount Athos: Motives and Bulgarian Places of Worship; L. Galabova. Sociocultural Roles of Transborder East Orthodox Christian Pilgrimage in Rethinking Sacral Elements of Bulgarian National Identity). The contribution of L. and Y. Gergovi, from the perspective of national, transnational and European, reflects on a cult (that of St. Cyril and St. Methodius) that is common for the Catholic and Orthodox Christians, which has been designed to be a geopolitical one, and is undoubtedly rather secular (L. Gergova, Gergova, Y. Official and Informal Commemoration Routes to St. Cyril and St. Methodius Heritage Sites in Europe). The following studies by B. Alexiev, M. Borisova, and E. Hein discuss the issues of national cultural (and natural) heritage abroad in terms of its valorization and popularization (B. Alexiev. Constructing Your Own Through the Alien: The Bulgarian Cultural Heritage in Istanbul; M. Borisova. Constructing Bulgarian Cultural Heritage Abroad: Mikulčice (Czech Republic) as a Pilgrimage Center; E. Hein. Preliminary Thoughts on the Cult of Mount Taishan Outside the Peoples Republic of China: Could It Be a Kind of Projection of Chineseness Throughout the World?).

Beside classic commemorative forms, the volume displays also various attractive presentations (that are not only an illustration but also a mechanism of migrant consolidation) of national cultural heritage - concerts (songs and dances) (L. Peycheva. Concert Practices of the Presentation of the Bulgarian Cultural Heritage Abroad (The Case of Iliya Lukov)). G. Grigorov's article considers national symbols and their ritual valuation (Gr. Har. Grigorov. Constructing National Territory through Ritual). N. Dimitrova, R. Witt, and E. Alexandrova study the role of historical figures and events and of symbols and myths that they are associated with the process of religious and national bases formation (N. Dimitrova. Crossing Boarders: Maria Skobtsova and Russian Émigrés in Paris on the Routes to Freedom; R. Witt. Singleminded Multitasking: 
Heinrich der Lŏwe Visits the Lands of the Eastern Roman Empire in 1172; E. Alexandrova. Commemorative Celebrations and Homage in Connection with the Ilinden Uprising of 1903).

The next texts examine the importance of national heritage for the tourism branch and the potential of the Balkan military history for dynamizing tourist practices and messages (O. Akbulut, Y. Ekin. Tourism Potential of Battlefields of Balkan Wars (1912-1913): A Comparison of Turkey and Bulgaria; N. Vukov. Transborder Commemorations and the Issue of Time Distance: The BulgarianTurkish Border in the Perspective of Historical Temporality). The article that discusses historical battlefields and military monuments in terms of space sacralization and touristic practices is also intriguing (O. Akbulut, Y. Ekin. Battles between Turkish and Opponent Parties (1910-1922) Considered According to the Site Sacralisation Theory).

The idea of the studies in the volume as well as its realization offers an interesting and vivid discussion on issues that are important in dynamic present: the role of the national dimensions of the transnational, the need for getting to know and (no less) adapting, integrating, and accepting "own/alien" in a global world that seems to be looking for the national. Publishing the articles in English makes the volume accessible to the international, scientific community.

The volume edited by L. Gergova, V. Voskresenski, and Y. Gergova, 'Transborder Commemoration Routes and Rituals' is among the achievements of contemporary Bulgarian (and generally Balkan) ethnology and cultural anthropology, and is interesting both for scholars and a wide audience.

Ekaterina Anastasova

Ekaterina Anastasova, PhD, Associate Professor, Head of the Department of Comparative Folklore Studies, Institute of Ethnology and Folklore Studies with Ethnographic Museum at the Bulgarian Academy of Sciences, Sofia. She is an ethnolinguist and folklorist, working in the field of social and cultural development of the contemporary society. Her research explores the problems of ethnicity, religiosity and nationalism in the post-socialist space. 